\title{
ENGLISH TEACHERS' STRATEGIES IN TEACHING CONVERSATION MATERIALS AT HIGH SCHOOL LEVEL IN MEDAN
}

\author{
Erikson Saragih, Audina Nauli, Rina Septiyan Damaiyana Simbolon \\ Gabriella Patricia L.Tobing, Rany Octorita Nababan, Novi Triani Hutagalung \\ Faculty of English Education \\ University of Prima Indonesia, Medan \\ E-mail: erikson.saragih@unprimdn.ac.id, asrifaldha123@gmail.com, rinaseptiyan@yahoo.co.id \\ gebytobing97@yahoo.co.id, ranyoctorita59@gmail.com, novihutagalung47@ gmail.com
}

\begin{abstract}
ABSRACT
This study is aimed at findings the strategies that used by English teachers' in teaching conversation material at high school level in Medan. It is investigated five English teachers in teaching conversation materials through strategies. In collecting the data, interview, classroom observation and FGD were used as instruments to identify teachers' strategies in teaching conversation. The result showed that the strategy used by the English teachers' strategies in teaching conversation materials at high school level in Medan were role play, pair work, drilling and group discussion. The first and second English teachers' used group discussion strategy, because through strategy the teaching learning process more enjoyed, relaxed, and it can make the students active in speaking. The third teacher used the role play strategy because students could practice their speaking skills directly in front the class. The forth teacher used drilling strategy, because it helped the students in improving their pronunciation. And the last teacher used pair work strategy, because the strategy could make students be more active in the class and they had an opportunity to speak English in pair. Students could be more confident when speak in front of their pair, and also they could be more active in the class.
\end{abstract}

Keywords: Teaching strategy, Teaching speaking, Conversation

\section{INTRODUCTION}

Teaching as process was to give information to the learners. When doing teaching, a teacher transfers his knowledge, message and skills to the students. Teaching also created interaction between a teacher and his students. To support their expected goals in teaching, teachers could use some different strategies to support language skills (listening, reading, speaking and writing). Teaching speaking was the teacher teaches the students to speak in a language target with the good accent, word, and sentences. The purpose of teaching speaking was to improve the oral production of the students. According to Nunan (2003), teaching speaking means that the teachers teach the students to: produce the English speech sound, word, sentence, stress intonation pattern, the rhythm. And also select the suitable words and sentences according to the proper social, setting, audience, situation, and subject matter.

Teaching strategies were various ways used by teachers in teaching learning process. Teaching strategies was important since they determine teachers' success in achieving teaching goals. Strategies were used by teacher should be interesting and could capture students' attention. Especially for teaching speaking, strategies should make students able to communicate efficiently and effectively. According to Brown (2000) states that strategies are specific methods of approaching a problem, modes operation for achieving a particular end planned designs for controlling and manipulating certain information. In teaching speaking, the teachers needed some strategies to help them in transferring the materials with good ways. By using the strategies, the teacher could achieve the indicators of the materials. And also learning with strategies was more interesting for the students to learn English especially in speaking. There were some strategies that can be used by English teacher in teaching speaking especially conversation, such as pair work, role play, drilling, and group discussion.

There were still many students could not speak fluently. They had many difficulties when they wanted to speak in English especially in conversation. One of problems was that the students could not communicate in English well. They said that they did not know what to say and how to speak up their mind because of lack of vocabulary. There were some conversations sections were not used or applied the interesting strategies in the class. That's why the writer is interested to discuss this topic because each suggestion of the literature when discussing about conversation, the writer saw that the conversation material was still rare in the school.

The reason of this research is needed, such as: To find out the English teachers' strategies in teaching conversation at high school level; to describe the process of the strategies that English teachers used in teaching conversation at high school level; to identify the reason of English teacher chose the strategies in teaching conversation at high school level. 
The Importance of this research was able to know how and what the strategy that could be used in teaching conversation. It could help students to increase their vocabularies, to correct and to improve their pronunciation by using strategy that used by English teacher.

\section{Conversation}

There were six categories of speaking according to Brown (2004). Imitative; means imitating a word, phrase or sentence. And it focused on pronunciation. The teacher used drilling in the teaching learning process. So the students could listen and repeat some word. Intensive; refers to practice some phonological and grammatical aspect of language. It usually did in pair or group work. For example, reading aloud in paragraph, reading information, chart and etc. Responsive; is an interaction and test comprehension but somewhat limited level of very short conversation, standard greeting, small talk, simple request and comment. In this section, the teacher and students could reply the questions, comment, giving direction and etc. Transactional (dialogue); the purpose of this performance is to exchange specific information and to extend form of responsive languages. Interpersonal (dialogue); interpersonal dialogue is carried out to maintain social relationship than for the transmission of the facts and information. Examples, the conversations because it involved some factors such as emotionally charged language, slag, a covert (agenda) and etc. Extensive; it was monologue that given by teachers which form of reports, short speech, or summaries. It was also more formal. Its purpose was to report and retell a story.

According to Marianne Celce and Murcia (2001: 108), one of speaking activity was conversation which is the most fundamental form of oral communication.. But only a few of them have either the opportunity or confidence in unplanned conversation with native speakers. Maley (1988:1) states that conversation is an activity that involves two or more people has the right thing to talk and listen without any agenda or content. And the purpose of conversation is receiving and giving the information, such as social relationships, negotiation of status or social roles, and etc. Maley (1988:1) also states that there are some roles that usually followed at normal conversation, such as only one person speaks at a time, the speaker can change, the length of conversation varies, there are some roles to speak in the party, and the content of the speaking is not specified or the content is free.

\section{Previous Research}

In this relation, there are some previous studies related to the topic, such as Journal of $\mathrm{PhD}$ in pedagogies, associate professor of translation department created by Oksana Ye. Milova with the title "Teaching Conversation in English Language Classroom: Conversational Techniques" that the conclusion of the study showed teaching conversation is very important for foreign language learning. The ability to communicate the target language clearly contributed to success of language learners in daily life. So the teachers should pay attention to teaching conversation. Teachers should make the class interesting. By this aim, various conversational techniques can be performed in English language classroom to develop the basic conversational skills. The various conversational techniques are, such as small group discussion, improvisation, debates, stimulation, role play and other.

\section{Teaching Strategies}

Teaching strategies were various ways used by teachers in teaching learning process. Teaching strategies was important since they determined teachers' success in achieving teaching goals. Strategies are used by teacher should be interesting and can capture students' attention. Especially for teaching speaking, strategies should make students able to communicate efficiently and effectively. According to Brown (2000) states that strategies are specific methods of approaching a problem, modes operation for achieving a particular end planned designs for controlling and manipulating certain information.

In this study, the writer was interested in identifying the teachers' strategies in teaching conversation. Many research have done a research about teaching strategies in teaching speaking, that are:

a. Role Play According to Nunan (2003), role play is a good activity for speaking in the classroom. Marianne Celce and Murcia (2001), role play is a speaking activity which is suitable for practicing the socio cultural variations in speech acts, such as complimenting, complaining, and etc. Harmer (2003) states that role play is stimulation the real world in the same way, where the participants have to speak and act from their new character's point of view. Harmer (2003) also argues that there are advantages of role play, such as role play is fun and also motivating activities, role play gives students to be more honest or forthright in their opinions and behavior without having responsibility for what they say in the way that they do when they are speaking for themselves, and it allows students to use a much wider range of language.

b. Pair-Work According to Zohairy (2014), pair-work is an effective strategies that put two students or three students in group. By putting students in this pair-work makes their interaction 
meaningful and as a result will increase their language production. Harmer (2003) states that in pair work students can practice the language together. And also the students can write, predict of the reading, and act what they have listened to, read, or seen. Harmer (2003) also argues that the advantages of pair work, such as pair work can increase the amount of speaking time that students get in the class, it allows students to act and work independently without guidance of the teacher, it recognizes that 'two heads are better than one', it makes class more relaxed and friendly place and it is relatively quick and easy to organize. It also has a disadvantage, such as pair work is very noisy and some of teachers and students may dislike it and make teachers fell worried that they will lose control of their class, it can make students veer away from the point of the exercise or students can talk about other, and also many students feel that they would rather relate to the teacher as individuals than interact with other that weak as they are.

c. Drilling According to Harmer (2001) says drilling is way in getting students to demonstrate and practice their ability to use specific language item in a controlled manner. Additionally Thornbury (2005) says drilling has come advantages including (i) to make students pay attention to a new materials that presented by teachers; (ii) explain words, phrases, or sentences to the students so the students can remember it in their mind in long term memory; (iii) and to provide means of finding articulator control over language.

d. Group discussion According to Maulidar, at, el (2019:86) said that group discussion is one of an effective strategy in teaching speaking because in group discussion students can be more active sharing their idea inside their thought as it encourages students to speak up as a tool of interaction in discussion. According to Harmer (2001), conducting group discussion can give some advantages, such as (i) it can enhance talking for each students; (ii) encourage cooperation and negotiation; (iii) rehearsal to increase students' problem solving.

\section{METHODOLOGY}

This study would be conducted by using qualitative approach with phenomenological design, because the data in this study were descriptive qualitative data. According to Creswell (2007), the qualitative research is a research study which is needed to explore phenomenon from the participants of education. And qualitative research is exploring, analyzing the information and writing the report of the information from the participants. In this study, the qualitative data would be obtained through to observation and interview.

The subject of the study would be the high school's English teachers in Medan. There were five teachers. The writer chose the senior high school's teachers of high school level because the writer does the observation and the study has ever conducted before. There were some reasons the writer chose the topic. First, the writer wanted to know teachers' strategies in teaching conversation. Second, the writer wanted to know the impact of using strategies in teaching conversation for students. The study would be conducted within one week. And it would be conducted around third week of July which is July $18^{\text {th }}$ to $26^{\text {th }}, 2019$.

The study would apply qualitative data which is description or narrative. The qualitative data would be taken from observation sheets are to describe the situation during the teaching and learning process and interview questions were to identify and analyze the strategies that used by English teachers in teaching conversation through sound or video recording. According to Creswell (2007:135), recording observational session can be useful information for developing a chronology of the ways of activities unfolded during the class session. Interview enables a person to take notes during interview about the responses of the interview. The process of recording information used various forms, such as observational fieldnotes, interview write-ups, photographing, sound recording, and documents.

Collecting the data of this study came from the result in collecting data which would do in English teachers' strategies in teaching conversation materials. The writer would interview the teacher, observe and write down every activities of the subject base on what writer will find during research take place. In observing, the writer will take some picture and recording during the teaching learning process. After getting the data the writer analyzed it by selecting the data and transforming it into transcript. Then the writer changed it into graphs or scheme. By looking the graphs or scheme, the writer took the summary or conclusion of the data.

\section{RESULT}

This study was used interview to collect the data. Researchers had some questions related to the teachers' strategies in teaching conversation at High School level. The researchers asked the subjects to answer the interview questions to get the data. The following table showed the percentage of strategies in teaching conversation. 
Table 1.1 Percentage of English Teachers' Strategies In teaching Conversation

\begin{tabular}{|l|c|c|c|c|c|}
\hline $\begin{array}{l}\text { English } \\
\text { Teachers } \\
\text { Strategies }\end{array}$ & $1^{\text {st }}$ teacher & $2^{\text {nd }}$ teacher & $3^{\text {rd }}$ teacher & $4^{\text {th }}$ teacher & $5^{\text {th }}$ teacher \\
\hline Pair work & - & - & - & - & $\sqrt{ }$ \\
\hline Role play & - & - & $\sqrt{ }$ & - \\
\hline Drilling & - & - & - & - & - \\
\hline $\begin{array}{l}\text { Group } \\
\text { Discussion }\end{array}$ & $\sqrt{ }$ & $\sqrt{ }$ & - & - & - \\
\hline
\end{tabular}

According to the table above the English teachers used some strategies in teaching conversation, such as: pair work, role play, drilling, and group discussion. And each teacher had some reason and the way in using the strategies. The answer would be showed in the following table below.

Teacher 1

Table 1.2 The English Teachers' Answer

\begin{tabular}{|c|c|}
\hline Questions & Answer \\
\hline $\begin{array}{l}\text { 1. What strategy is used by English } \\
\text { teachers in teaching conversation? }\end{array}$ & Group Discussion \\
\hline $\begin{array}{l}\text { 2. Why do English teachers apply the } \\
\text { strategy in teaching conversation? }\end{array}$ & $\begin{array}{l}\text { The students can be more focused on the } \\
\text { topic. }\end{array}$ \\
\hline $\begin{array}{l}\text { 3. How do English teachers apply the } \\
\text { strategies in teaching conversation? }\end{array}$ & $\begin{array}{l}\text { - The teacher divides the students into } \\
\text { some groups which has } 5 \text { students in } \\
\text { each group. } \\
\text { - The teacher gives difference topic to } \\
\text { each groups related to the material } \\
\text { - And the students do the discussion in the } \\
\text { group } \\
\text { After discussing the topic, the teacher } \\
\text { asks the students to share their idea that } \\
\text { they have discussed in the group in front } \\
\text { of the class. } \\
\text { The last the teacher asks the students to } \\
\text { ask or answer the question related to the } \\
\text { topic. }\end{array}$ \\
\hline $\begin{array}{l}\text { 4. Does the strategy that use by English } \\
\text { teacher improve the student speaking } \\
\text { ability? }\end{array}$ & Yes, it does \\
\hline 5. What are the advantages of the strategy? & $\begin{array}{l}\text { - For the teacher: the teacher can be more } \\
\text { enjoyed in teaching learning process } \\
\text { - For the students: the students can be } \\
\text { more focused. And the topic can be } \\
\text { understood by the students. }\end{array}$ \\
\hline $\begin{array}{l}\text { 6. What are the weaknesses of the } \\
\text { strategy? }\end{array}$ & $\begin{array}{l}\text { Some of students cannot focus in } \\
\text { discussion because they talk about other } \\
\text { topic in the group }\end{array}$ \\
\hline $\begin{array}{l}\text { 7. What are the difficulties of using the } \\
\text { strategy in teaching conversation? }\end{array}$ & $\begin{array}{l}\text { In applying the strategy, the teacher gets } \\
\text { the difficulties, such as: the student do } \\
\text { not speak in target language in } \\
\text { discussion, sometimes the class out of } \\
\text { control if the teacher does not pay }\end{array}$ \\
\hline
\end{tabular}




\begin{tabular}{|l|l|}
\hline & attention to each group. \\
\hline $\begin{array}{l}\text { 8. How does the students respond to the } \\
\text { strategy that used by English teacher in } \\
\text { teaching conversation? }\end{array}$ & $\begin{array}{l}\text { The responds is good. Because many of } \\
\text { the students ask some question to the } \\
\text { teacher related to material so the class is } \\
\text { more active. }\end{array}$ \\
\hline
\end{tabular}

Teacher 2

\begin{tabular}{|c|c|}
\hline Questions & Answer \\
\hline $\begin{array}{l}\text { 1. What strategy is used by English } \\
\text { teachers in teaching conversation? }\end{array}$ & Group Discussion \\
\hline $\begin{array}{l}\text { 2. Why do English teachers apply the } \\
\text { strategy in teaching conversation? }\end{array}$ & Discussion can make the students speak \\
\hline $\begin{array}{l}\text { 3. How do English teachers apply the } \\
\text { strategies in teaching conversation? }\end{array}$ & $\begin{array}{l}\text { - The teacher divides the students into } \\
\text { some groups which has } 4 \text { students in } \\
\text { each group. } \\
\text { - The teacher gives topic to the groups } \\
\text { related to the material } \\
\text { - And the students do the discussion in the } \\
\text { group } \\
\text { The teacher and students discuss the } \\
\text { topic together }\end{array}$ \\
\hline $\begin{array}{l}\text { 4. Does the strategy that use by English } \\
\text { teacher improve the student speaking } \\
\text { ability? }\end{array}$ & Yes, it does \\
\hline 5. What are the advantages of the strategy? & $\begin{array}{l}\text { - It can make the students speak in target } \\
\text { language. }\end{array}$ \\
\hline $\begin{array}{l}\text { 6. What are the weaknesses of the } \\
\text { strategy? }\end{array}$ & $\begin{array}{l}\text { Some of the students still do not have } \\
\text { many vocabularies and they do not } \\
\text { know how to pronounce it }\end{array}$ \\
\hline $\begin{array}{l}\text { 7. What are the difficulties of using the } \\
\text { strategy in teaching conversation? }\end{array}$ & $\begin{array}{l}\text { In applying the strategy, the teacher gets } \\
\text { the difficulty which some of the students } \\
\text { still cannot speak English well }\end{array}$ \\
\hline $\begin{array}{l}\text { 8. How does the students respond to the } \\
\text { strategy that used by English teacher in } \\
\text { teaching conversation? }\end{array}$ & $\begin{array}{l}\text { The responds is good. Because many of } \\
\text { the students ask some question to the } \\
\text { teacher related to material }\end{array}$ \\
\hline
\end{tabular}

Teacher 3

\begin{tabular}{|c|c|}
\hline Questions & Answer \\
\hline $\begin{array}{l}\text { 1. What strategy is used by English } \\
\text { teachers in teaching conversation? }\end{array}$ & Role play \\
\hline $\begin{array}{l}\text { 2. Why do English teachers apply the } \\
\text { strategy in teaching conversation? }\end{array}$ & $\begin{array}{l}\text { Students can practice their speaking } \\
\text { skills directly in front the class }\end{array}$ \\
\hline
\end{tabular}




\begin{tabular}{|c|c|}
\hline $\begin{array}{l}\text { 3. How do English teachers apply the } \\
\text { strategies in teaching conversation? }\end{array}$ & $\begin{array}{l}\text { - The teacher divides the students into } \\
\text { some groups which has } 4 \text { students in } \\
\text { each group. } \\
\text { The teacher gives topic or the script to } \\
\text { the groups that must be acted or } \\
\text { practiced by the students in front of the } \\
\text { class } \\
\text { Teacher choose the characters for the } \\
\text { students } \\
\text { The students memorize their dialogues } \\
\text { - The last, the students act or practice } \\
\text { their dialogue in front of the class } \\
\text { The teacher asks another students to } \\
\text { answer the question related to the } \\
\text { dialogue that has been showed before }\end{array}$ \\
\hline $\begin{array}{l}\text { 4. Does the strategy that use by English } \\
\text { teacher improve the student speaking } \\
\text { ability? }\end{array}$ & Yes, it does \\
\hline 5. What are the advantages of the strategy? & $\begin{array}{l}\text { - Through the role play, the students can } \\
\text { be more confident in practicing their } \\
\text { speaking skills } \\
\text { - The strategy can increase the students' } \\
\text { vocabularies }\end{array}$ \\
\hline $\begin{array}{l}\text { 6. What are the weaknesses of the } \\
\text { strategy? }\end{array}$ & $\begin{array}{l}\text { Many students still cannot pronounce } \\
\text { the word well. }\end{array}$ \\
\hline $\begin{array}{l}\text { 7. What are the difficulties of using the } \\
\text { strategy in teaching conversation? }\end{array}$ & $\begin{array}{l}\text { In applying the strategy, the teacher gets } \\
\text { the difficulty which Many students have } \\
\text { the difficulties in pronouncing new } \\
\text { words because their lack of } \\
\text { vocabularies. }\end{array}$ \\
\hline $\begin{array}{l}\text { 8. How does the students respond to the } \\
\text { strategy that used by English teacher in } \\
\text { teaching conversation? }\end{array}$ & $\begin{array}{l}\text { Some of the students are excited in } \\
\text { practicing because they can act as the } \\
\text { characters. }\end{array}$ \\
\hline
\end{tabular}

Teacher 4

\begin{tabular}{|c|l|}
\hline \multicolumn{1}{|c|}{ Questions } & \multicolumn{1}{|c|}{ Answer } \\
\hline $\begin{array}{l}\text { 1. What strategy is used by English } \\
\text { teachers in teaching conversation? }\end{array}$ & Drilling \\
\hline 2. Why do English teachers apply the & $\begin{array}{l}\text { Students can be more focused on } \\
\text { teacher's explanation in new material } \\
\text { because the strategy has to focus on } \\
\text { pronunciation and articulation. }\end{array}$ \\
\hline
\end{tabular}




\begin{tabular}{|c|c|}
\hline $\begin{array}{l}\text { 3. How do English teachers apply the } \\
\text { strategies in teaching conversation? }\end{array}$ & $\begin{array}{l}\text { - The teacher reads the dialogue } \\
\text { The teacher asks the students to repeat } \\
\text { the dialogue together after the teacher } \\
\text { line by line } \\
\text { - The teacher asks the students to repeat } \\
\text { the dialogue individually in chorus } \\
\text { - The teacher listens and corrects if the } \\
\text { teacher detects an error } \\
\text { - The teacher asks the students to replace } \\
\text { the word with the other word } \\
\text { The teacher writers the text of the } \\
\text { dialogue on the whiteboard } \\
\text { The teacher asks the students to make } \\
\text { their own dialogue contains of the key } \\
\text { structure } \\
\text { All of the students' speech performance } \\
\text { in front of the class }\end{array}$ \\
\hline $\begin{array}{l}\text { 4. Does the strategy that use by English } \\
\text { teacher improve the student speaking } \\
\text { ability? }\end{array}$ & Yes, it does \\
\hline 5. What are the advantages of the strategy? & $\begin{array}{l}\text { - It helps the students in improving the } \\
\text { topic of the subject } \\
\text { It makes the students to understand the } \\
\text { dialogue because the students will try to } \\
\text { know the meaning of the words or the } \\
\text { sentences in completing dialogue }\end{array}$ \\
\hline $\begin{array}{l}\text { 6. What are the weaknesses of the } \\
\text { strategy? }\end{array}$ & $\begin{array}{l}\text { Many students still cannot pronounce the } \\
\text { word well. }\end{array}$ \\
\hline $\begin{array}{l}\text { 7. What are the difficulties of using the } \\
\text { strategy in teaching conversation? }\end{array}$ & $\begin{array}{l}\text { Students feel difficult to pronounce } \\
\text { certain words because in English, the } \\
\text { spellings of the words are sometimes } \\
\text { different from their pronunciations. } \\
\text { Therefore, they find it hard to pronounce } \\
\text { words correctly }\end{array}$ \\
\hline $\begin{array}{l}\text { 8. How does the students respond to the } \\
\text { strategy that used by English teacher in } \\
\text { teaching conversation? }\end{array}$ & $\begin{array}{l}\text { Students have quite the same responses } \\
\text { toward the strategies used in the } \\
\text { classroom. }\end{array}$ \\
\hline
\end{tabular}

Teacher 5

\begin{tabular}{|c|c|}
\hline Questions & Answer \\
\hline $\begin{array}{l}\text { 1. What strategy is used by English } \\
\text { teachers in teaching conversation? }\end{array}$ & Pair work \\
\hline $\begin{array}{l}\text { 2. Why do English teachers apply the } \\
\text { strategy in teaching conversation? }\end{array}$ & $\begin{array}{l}\text { Students can be more active in the class } \\
\text { and they have an opportunity to speak } \\
\text { English in pair. }\end{array}$ \\
\hline
\end{tabular}




\begin{tabular}{|c|c|}
\hline $\begin{array}{l}\text { 3. How do English teachers apply the } \\
\text { strategies in teaching conversation? }\end{array}$ & $\begin{array}{l}\text { - The teacher gives students worksheet } \\
\text { that consists of the pictures and they } \\
\text { have to work in pair } \\
\text { - Each student has to ask his/her pair } \\
\text { some questions according to the picture } \\
\text { - When student gives a question, her } \\
\text { friend has to answer a question. And } \\
\text { they have to do it vice versa } \\
\text { - After her friend answer her questions, } \\
\text { her friend will ask her a question and } \\
\text { she has to answer too. }\end{array}$ \\
\hline $\begin{array}{l}\text { 4. Does the strategy that use by English } \\
\text { teacher improve the student speaking } \\
\text { ability? }\end{array}$ & Yes, it does \\
\hline 5. What are the advantages of the strategy? & $\begin{array}{l}\text { - Students can be more confident when } \\
\text { speak in front of their pair, and also they } \\
\text { can be more active in the class }\end{array}$ \\
\hline $\begin{array}{l}\text { 6. What are the weaknesses of the } \\
\text { strategy? }\end{array}$ & $\begin{array}{l}\text { The condition of the class will be } \\
\text { uncontrolled, because the students will } \\
\text { be noisy when practice in pair. And the } \\
\text { teacher needs more duration in the class. }\end{array}$ \\
\hline $\begin{array}{l}\text { 7. What are the difficulties of using the } \\
\text { strategy in teaching conversation? }\end{array}$ & Difficult in control the class \\
\hline $\begin{array}{l}\text { 8. How does the students respond to the } \\
\text { strategy that used by English teacher in } \\
\text { teaching conversation? }\end{array}$ & $\begin{array}{l}\text { The respond is good. Because they can } \\
\text { be confident when speak in front of their } \\
\text { friend }\end{array}$ \\
\hline
\end{tabular}

According to the data above, the strategies that usually used by English teachers at High School level in teaching conversation is Role play, Pair Work, Drilling and Group Discussion. As we can see in the table, the first subject used Group Discussion as strategy in teaching conversation to make the students could be more focused on the topic. There were some reasons why do teachers apply the strategy. Firstly, the learning process would be easier and not boring. Secondly, the students would be more active in speaking and asking in English. In applying Group Discussion, the teacher divided the students into some groups and each group had five students with different topic. After doing the discussion, the teacher asked one of them to share their idea about the topic in front of the class and the other students asked about the topic that has been shared. And the second subject also used Group Discussion to make the students practice in group easily but in applying the Group Discussion, there were some students that used their own language in speaking because of lack vocabulary. The third subject used role paly in teaching conversation. The reason the teacher used the strategy because students could practice their speaking skills directly in front the class. Through the role play, the students could be more confident in practicing their speaking skills and the strategy could increase the students' vocabularies. The application of the strategy, firstly the teacher divided the students into some groups which has 4 students in each group. The teacher gives topic or the script to the groups that had to be acted or practiced by the students in front of the class. Teacher chose the characters for the students. The students memorized their dialogues. The last, the students acted or practiced their dialogue in front of the class. And the teacher asked other students to answer the question related to the dialogue that has been showed before. The forth subject used drilling strategy in teaching conversation. The reason because students could be more focused on teacher's explanation in new material because the strategy had to focus on pronunciation and articulation. Drilling helped the students in improving the topic of the subject. And it made the students to understand the dialogue because the students would try to know the meaning of the words or the sentences in completing dialogue. The procedure of the strategy is firstly the teacher read the dialogue. The teacher asked the students to repeat the dialogue together after the teacher line by line. The teacher asked the students to repeat the dialogue individually in chorus. The 
teacher listened and corrected if the teacher detects an error. The teacher asked the students to replace the word with the other word. The teacher wrote the text of the dialogue on the whiteboard. The teacher asked the students to make their own dialogue contains of the key structure. The last, all of the student spoke their performance in front of the class. The last subject used pair work strategy in teaching conversation. The reason because the strategy could make students be more active in the class and they had an opportunity to speak English in pair. Students could be more confident when speak in front of their pair, and also they could be more active in the class. The application of the strategy is first, the teacher gave students worksheet that consists of the pictures and they had to work in pair. Each student had to ask his/her pair some questions according to the picture. When student gave a question, her friend had to answer a question. And they had to do it vice versa. After her friend answered her questions, her friend would ask her a question and she had to answer too.

\section{CONCLUSION}

The conclusion an analysis of English teachers' strategies in teaching conversation materials as follow: The strategies are used by English teachers in teaching conversation materials are Role play, Pair work, drilling and Group discussion. The first teacher used the Group Discussion strategies, because the teaching learning process more enjoyed and relaxed. The second teacher used the Group Discussion strategies, because discussion can make the students active in speaking. The third teacher used role play strategy, because students could practice their speaking skills directly in front the class and the strategy is fun and motivating. The forth teacher used drilling strategy, because students could be more focused on teacher's explanation in new material because the strategy has to focus on pronunciation and articulation. And the last teacher used pair work strategy because students could be more active in the class and they had an opportunity to speak English in pair. All of the strategies above can be the references for the English teacher in teaching conversation. Thus, it is suggested that the teacher can use the suitable and interesting strategies in teaching conversation materials, because it can help the teacher to improve the students' ability in conversation. The teacher must be creative in teaching learning process.

\section{EFERENCES}

Ary, Donald. et, al. 2010. Introduction to Research in Education, ( $8^{\text {th }}$ edition). Wadsworth, Cengage Learning. Canada.

Brown, H. Douglas. 2000. Principles of Language Learning and Teaching, (4 $4^{\text {th }}$ edition). White Plains. San Francisco State University. Addison Wesley Longman. A Pearson Education Company.

Brown, H. Douglas. 2004. Teaching by Principles: An Interactive Approach to language pedagogy, $\left(2^{\text {nd }}\right.$ edition). Sun Francisco State University. Longman. Pearson Education, Inc.

Creswell, John. W. 2007. Qualitative Inquiry and Research Design: Choosing among Five Approaches, ( $2^{\text {nd }}$ ed.). University of Nebraska. Lincoln. Sage Publication, Inc.

Creswell, John. W. 2012. Educational Research: Planning, Conducting, and Evaluating Quantitative and Qualitative Research, (4 ${ }^{\text {th }}$ edition). University of Nebraska. Lincoln. Pearson Education, Inc.

Celce, M and Murcia. 2001. Teaching English as a Second or Foreign Language, ( $3^{\text {rd }}$ edition). United States of America.

Dornyei, Z and Sarah, T. 1994. Teaching Conversational skills Intensively: Course Content and Rational. ELT Journal. Vol 48. Oxford University Press.

Gill. P. et, al. 2008. Methods of Data Collection in Qualitative Research: Interview and Focus Groups. British Dental Journal. Vol 204 No 6. Nature Publishing Group.

Harmer, J. 2001. How to Teach English. Malaysia: Longman.

Harmer, J. 2003. The Practice of English language Teaching, ( $3^{\text {rd }}$ edition). Malaysia: Longman.

Maley A.1988. Resource Books for Teacher. Oxford University Press. Hongkong.

Maulidar, K. et, al. 2019. "Teacher's Strategies in Teaching Speaking for Cadets”. English Education Journal. University of Syiah Kuala. Banda Aceh

Miles. M.B. and A. M. Huberman. 1994. An Expanded Sourcebook Qualitative Data Analysis, (2 ${ }^{\text {nd }}$ edition). Sage Publication, Inc.

Milova, O. 2015. Teaching Conversation in English Language Classroom: Conversational Techniques. Boris Grinchenko Kyiv University. Kyiv. Google Scholar

Nunan, David. 2003. Practical English Language Teaching. New Work: Mc Graw Hill.

Zohairy, S. 2014. Effective Pair Work Strategies to Enhance Saudi Pre-Intermediate College Students' Language Production in Speaking Activities. European Scientific Journal. Vol 10 No.2.

Thornbury Scott. 2005. How to Teach Speaking. Longman. Pearson Education, Inc. 